\title{
Suppression of root-knot nematodes in potting mixes amended with different composted biowastes
}

\author{
T. D’ADDABBO ${ }^{1}$, I. PAPAJOVÁ $^{2}$, N. SASANELLI ${ }^{1}$, V. RADICCI ${ }^{1}$, M. RENČO ${ }^{2}$ \\ ${ }^{1}$ Institute for Plant Protection, Section of Nematology, Italian National Council of Researches, \\ Via G. Amendola 122/D, 70126 Bari, Italy, E-mail: t.daddabbo@ba.ipp.cnr.it; \\ ${ }^{2}$ Institute of Parasitology, Slovak Academy of Sciences, Hlinkova 3, 04001 Košice, Slovak Republic
}

\begin{abstract}
Summary
Suppressiveness of soil amendments with different rates of composted biowaste materials, olive pomace, municipal green wastes, sewage sludge and spent mushroom substrate, was evaluated against the root-knot nematode Meloidogyne incognita on tomato in potting mixtures. Soil amendments were applied at $0,10,25,50$ and $100 \mathrm{~g} \mathrm{~kg}^{-1}$ soil, according to a randomized block design with five replications for each treatment. Sixty days after tomato transplanting, nematode population density on plant roots and in soil and root gall infestation were assessed on each root system, and plant top and root weight were also recorded. Soil $\mathrm{pH}$, dry and organic matter content, total and ammoniacal nitrogen were analyzed at the same time. Olive pomace-based composts resulted in the highest nematode suppression $(73-97 \%$, according to the rate) and significantly reduced gall formation on tomato roots. Olive-waste compost affected positively tomato growth only in combination with sheep wool wastes, but it caused phytotoxicity when mixed with chicken manure and urea. Soil amendments with composted mushroom substrate also provided a consistent nematode suppression and a significant increase of plant growth, whereas composted municipal green wastes were more suppressive and positively affected tomato growth when combined with sewage sludge. Soil chemical parameters were scarcely affected by compost amendments, as organic matter was significantly increased only by the olive pomacederived composts and nitrogen content only at the highest rate of the five composts. Data from the experiment confirmed the potential of compost amendments for sustainable management of root-knot nematodes both in field and greenhouse container media, though their technical effectiveness and economic convenience are strictly dependent on a correct proportion and local availability of raw materials used in the composting process.
\end{abstract}

Keywords: root-knot nematodes; control; biowastes; compost

\section{Introduction}

A wrong disposal of large amounts of wastes generated by urban settlements and agro-industrial processes, such as sewage sludge, pomaces, manures and green wastes, may cause serious environment pollution (Williams, 2005). The composting process may represent a valuable alternative for the management of these wastes, as converting them into a stabilized form, destroying human and animal pathogens, recycling valuable plant nutrients and improving soil biological, chemical, and physical properties (De Bertoldi, 2008). In addition, composted raw materials from different origin were also found suppressive on several soil-borne fungal pathogens and on phytoparasitic nematodes (Bailey \& Lazarovits, 2003; Hu \& Qi, 2010; Renčo et al. 2011).

Root-knot nematodes (RKN), Meloidogyne species, are among the most damaging pests in agriculture, as spread worldwide and causing heavy yield losses on several economically relevant crops. Control of these pests is primarily based on chemical treatments, but the withdrawal of most nematicides available on the market has been leading to the investigation of more sustainable alternative control strategies (Greco \& Esmenjaud, 2004).

Soil amendments with a wide range of composted organic wastes were frequently documented for a suppressive effect on RKN, though their failure in nematode control was also reported (Akhtar \& Malik, 2000). Nematode suppression in a compost-amended soil may involve different mechanisms, such as direct toxicity of degradation products, an increase of natural nematode-antagonist microorganisms on the compost substrate or even the induction of a systemic aquired resistance in plants (Stirling, 1991; Zhang et al., 1996).

The suppressive effect of compost amendments on soil phytonematode populations is largely variable and scarcely predictable, as depending on the starting raw materials, the type of composting process and the maturity of the final 
Table 1. Raw material composition (\%) of composts used in the experiment

\begin{tabular}{cccccc}
\hline \multirow{2}{*}{ Raw material } & \multicolumn{5}{c}{ Percentage amounts } \\
\cline { 2 - 6 } & $\mathbf{C}_{\mathbf{1}}$ & $\mathbf{C}_{2}$ & $\mathbf{C}_{\mathbf{3}}$ & $\mathbf{C}_{\mathbf{4}}$ & $\mathbf{C}_{\mathbf{5}}$ \\
\hline Chicken manure & - & - & - & - & 8.0 \\
Fresh olive pomace & 72 & - & - & - & 87.4 \\
Sewage sludge & - & - & - & 30 & - \\
Sheep wool & 11 & - & - & - & - \\
Soil & - & 10 & - & - & - \\
Spent mushroom substrate & - & - & 100 & - & - \\
Straw & 17 & - & - & - & 4.0 \\
Urban green wastes & - & 90 & - & 70 & \\
Urea & - & - & - & - & 0.6 \\
\hline
\end{tabular}

product incorporated into the soil, and, therefore, should be specifically assessed for each compost. The study presented in this paper was aimed to a comparative evaluation of the nematicidal potential of five new composts, based on different municipal and agro-industrial raw wastes largely available in southern Italy, against the root-knot nematode Meloidogyne incognita (Kofoid et White) Chitw. on tomato (Solanum lycopersicum L.) in potting mixtures.

\section{Materials and methods}

Raw materials used for the formulation of the five composts are reported in Table 1 . Composts $\mathrm{C}_{1}$ and $\mathrm{C}_{5}$, were prevalently based on fresh olive pomace (FOP), combined with sheep wool wastes or chicken manure and urea, respectively. Composts $\mathrm{C}_{2}$ and $\mathrm{C}_{4}$ were mainly derived from municipal green wastes, integrated with soil or sewage sludge, respectively, whereas spent mushroom substrate was the starting material of compost $\mathrm{C}_{3}$. All composts were still at an experimental phase but $\mathrm{C}_{1}$, as also commercially available. Chemical analyses were preliminarily performed on a $100-\mathrm{g}$ composite sample of each compost and on a similar amount of soil from each treatment replicate at the end of the experiment. $\mathrm{A} \mathrm{pH}$ electrode was used to measure the $\mathrm{pH}$ values of a 1:10 w/v water extract of the composts and the soil samples, obtained after a 1-hour mechanical shake of samples in double distilled water. Total dry matter (DM) and inorganic matter percentage contents were obtained by drying sample portions for $4 \mathrm{~h}$ at $105{ }^{\circ} \mathrm{C}$ or $550{ }^{\circ} \mathrm{C}$, respectively, up to a constant weight. Percent organic matter (OM) was calculated as the difference between 100 and percent inorganic matter value. Total nitrogen content $\left(\mathrm{N}_{t}\right)$ was evaluated through a previous digestion of sample portions by a Didesdahl apparatus (HACH Company, Loveland, Colorado, USA), followed by distillation with $40 \% \mathrm{NaOH}$ (Bremner, 1996), whereas the water-soluble ammoniacal $\mathrm{N}\left(\mathrm{NH}_{4}^{+}\right)$fraction was determined by titration (Mulvaney, 1996).

Tomato plants were artificially infested with an Italian population of $M$. incognita and grown in a greenhouse for two months. The roots of these plants were finely chopped to quantify the number of eggs and juveniles by processing 6 root samples of $10 \mathrm{~g}$ each with a $1 \%$ aqueous solution of sodium hypoclorite (Hussey \& Barker, 1973). The chopped infested roots were then thoroughly mixed with $2 \mathrm{~kg}$ of steam sterilised sandy soil $\left(8 \mathrm{~h}\right.$ at $\left.100^{\circ} \mathrm{C}\right)$ and used as inoculum. Appropriate amounts of this inoculum were then added and mixed with a steam sterilised sandy soil $(64.4 \%$ sand, $18.7 \%$ silt, $16.9 \%$ clay, $0.8 \%$ organic matter and $7.5 \mathrm{pH})$ to provide an initial population density of 15 eggs and juveniles $\mathrm{ml}^{-1}$ soil $(P i)$.

The infested soil was then added with 25,50 and $100{\mathrm{~g} . \mathrm{kg}^{-1}}^{-1}$ soil rates of the five composts and mixtures were poured into $14 \mathrm{~cm}$ diam clay pots with five replicates of each compost $\mathrm{x}$ dose combination. Pots were arranged in a completely randomized block design, providing nonamended and infested or non-infested soil, as controls, in a glasshouse at $25 \pm 2{ }^{\circ} \mathrm{C}$.

A 1 month-old tomato cv. Roma seedling was transplanted in each pot four weeks after the compost incorporation.

During the experiment tomato plants were maintained in the glasshouse randomizing the position of the blocks and at the same time repositioning each plant within a block every five days, to avoid a block position effect and at the same time the factor position of the plant within the block. Plants received all the necessary maintenance, watered as required and maintained free of weeds. Two months after the transplant plants were uprooted and their height and fresh top and root weight were recorded. Gall formation caused by $M$. incognita was evaluated on each tomato root according to a $0-5$ scale in which $0=$ no galls, $1=1-2$ galls, $2=3-10$ galls, $3=11-30$ galls, $4=31-100$ galls and $5>100$ galls (Taylor \& Sasser, 1978). Final population density of $M$. incognita on tomato roots was determined processing each root system by sodium hypochlorite method (Hussey \& Barker, 1973), and then microscopically counting eggs and juveniles.

Table 2. Comparison of $\mathrm{pH}$, dry matter (DM), ammoniacal $\left(\mathrm{NH}_{4}^{+}\right)$ and total $\left(\mathrm{N}_{\mathrm{t}}\right)$ nitrogen contents of the tested composts

\begin{tabular}{|c|c|c|c|c|c|c|c|c|}
\hline \multirow{2}{*}{ Compost } & \multicolumn{8}{|c|}{ Chemical parameters } \\
\hline & \multicolumn{2}{|c|}{ pH } & \multicolumn{2}{|c|}{$\begin{array}{l}\text { DM } \\
(\%)\end{array}$} & $\underset{\left(\mathrm{mg} \mathrm{kg}^{-1}\right.}{\mathrm{NH}_{4}}$ & \multicolumn{2}{|c|}{ M) $\left(\mathrm{g} \mathrm{kg}^{-1}\right.$} & t \\
\hline $\mathbf{C}_{1}$ & 9.0 & $\mathrm{c}$ & 93.9 & $\mathrm{e}$ & 49.1 & $\mathrm{c}$ & 22.0 & $\mathrm{~d}$ \\
\hline $\mathbf{C}_{2}$ & 8.5 & $\mathrm{~b}$ & 65.8 & $\mathrm{c}$ & 69.7 & d & 18.1 & $\mathrm{c}$ \\
\hline $\mathbf{C}_{3}$ & 7.9 & $\mathrm{a}$ & 47.6 & a & 50.0 & $\mathrm{c}$ & 23.8 & $\mathrm{~d}$ \\
\hline $\mathrm{C}_{4}$ & 7.9 & $\mathrm{a}$ & 56.2 & $\mathrm{~b}$ & 0.1 & a & 7.7 & $\mathrm{a}$ \\
\hline $\mathrm{C}_{5}$ & 10.0 & $\mathrm{~d}$ & 79.5 & d & 38.6 & $\mathrm{~b}$ & 14.3 & $\mathrm{~b}$ \\
\hline
\end{tabular}

Data followed by the same letters on the same column are not significantly different according to Least Significant Difference's Test $(\mathrm{P} \leq 0.05)$ 
Moreover, a $100 \mathrm{~g}$ soil sample was taken from each pot to measure the chemical parameters as described above.

All data were subjected to a one-way or factorial analysis of variance and treatment means were compared using Fisher's Least Significant Difference pairwise procedure at $\mathrm{P} \leq 0.05$. Nematode data were $\operatorname{Ln}(\mathrm{x}+1)$ transformed before statistical analysis, due to homogenisation of error variances. All statistical analyses were performed using the PlotIT program.

\section{Results}

Analysis of composts

Values of $\mathrm{pH}$ were slightly above neutrality in composts $\mathrm{C}_{3}$ and $\mathrm{C}_{4}$, and clearly alkalyne in $\mathrm{C}_{1}, \mathrm{C}_{5}$ and, at a less extent, in $\mathrm{C}_{2}$ (Table 2). Dry matter content varied largely among materials, as ranging from 47.6 to a $94 \%$ of $\mathrm{C}_{3}$ and $\mathrm{C}_{1}$, respectively. $\mathrm{N}_{\mathrm{t}}$ amounts ranged from the $22-24 \mathrm{~g} \mathrm{~kg}^{-1}$ soil of $C_{1}$ and $C_{3}$, respectively, to the $7.7 \mathrm{~g} \mathrm{~kg}^{-1}$ in $C_{4}$,

Table 3. Effect of soil treatments with different composts on soil chemical parameters at the end of the experiment

Treatment

\begin{tabular}{|c|c|c|c|c|c|c|c|c|c|c|c|}
\hline \multirow[t]{2}{*}{ Compost } & \multirow{2}{*}{$\begin{array}{c}\begin{array}{c}\text { Rate } \\
\left(\mathrm{g} \mathrm{kg}^{-1} \text { soil }\right)\end{array} \\
10\end{array}$} & \multicolumn{2}{|c|}{ pH } & \multicolumn{2}{|c|}{$\begin{array}{c}\text { Dry matter } \\
(\%)\end{array}$} & \multicolumn{2}{|c|}{$\begin{array}{c}\text { Organic matter } \\
(\%)\end{array}$} & \multicolumn{2}{|c|}{$\underset{\left(\mathrm{mg} \mathrm{kg}^{-1} \text { soil }\right)}{\operatorname{Ammmoniacal} \text { nitrogen }}$} & \multicolumn{2}{|c|}{$\begin{array}{l}\text { Total nitrogen } \\
\left(\mathrm{g} \mathrm{kg}^{-1} \text { soil }\right)\end{array}$} \\
\hline & & $8.8^{(1)}$ & $\mathrm{bcde}^{(2)}$ & 91.4 & cdef & 2.1 & abcd & 7.5 & $a b$ & 2.96 & $a b c$ \\
\hline \multirow{3}{*}{$\mathbf{C}_{1}$} & 25 & 8.8 & bcde & 92.4 & ef & 2.7 & bcdef & 10.9 & bc & 3.02 & $a b c$ \\
\hline & 50 & 8.7 & bcde & 88.0 & bcde & 3.4 & fg & 17.1 & e & 3.49 & $a b c$ \\
\hline & 100 & 8.7 & bcd & 90.9 & cdef & 5.6 & $\mathrm{~h}$ & 29.2 & $\mathrm{f}$ & 9.34 & e \\
\hline \multirow{4}{*}{$\mathbf{C}_{2}$} & 10 & 9.0 & defgh & 88.4 & bcde & 2.1 & abcd & 17.8 & e & 3.05 & $a b c$ \\
\hline & 25 & 9.0 & defgh & 91.0 & cdef & 2.0 & abcd & 18.4 & $\mathrm{e}$ & 2.94 & $a b c$ \\
\hline & 50 & 9.1 & efgh & 90.6 & cdef & 2.2 & abcde & 16.2 & de & 3.81 & $a b c$ \\
\hline & 100 & 9.1 & efgh & 91.9 & def & 2.8 & cdefg & 17.2 & e & 6.57 & d \\
\hline \multirow{4}{*}{$\mathbf{C}_{3}$} & 10 & 9.1 & efgh & 88.1 & bcde & 1.8 & $a b$ & 15.5 & cde & 2.09 & $\mathrm{a}$ \\
\hline & 25 & 8.9 & cdefgh & 90.6 & cdef & 2.3 & abcde & 15.9 & cde & 4.27 & $\mathrm{bc}$ \\
\hline & 50 & 8.6 & $a b c$ & 92.5 & ef & 2.2 & abcde & 18.6 & e & 2.37 & $\mathrm{a}$ \\
\hline & 100 & 8.4 & $\mathrm{a}$ & 93.2 & $\mathrm{f}$ & 3.1 & efg & 17.9 & $\mathrm{e}$ & 4.59 & $\mathrm{c}$ \\
\hline \multirow{4}{*}{$\mathrm{C}_{4}$} & 10 & 8.7 & bcde & 93.6 & $\mathrm{f}$ & 1.8 & $a b c$ & 8.8 & $a b$ & 2.01 & $\mathrm{a}$ \\
\hline & 25 & 8.6 & $a b$ & 90.9 & cdef & 2.3 & abcde & 8.6 & $a b$ & 2.00 & $\mathrm{a}$ \\
\hline & 50 & 8.9 & bcdefg & 90.4 & cdef & 2.5 & abcdef & 11.2 & bcd & 4.26 & $\mathrm{bc}$ \\
\hline & 100 & 8.8 & bcdef & 91.1 & cdef & 3.0 & defg & 17.5 & e & 7.22 & $d$ \\
\hline \multirow{4}{*}{$\mathrm{C}_{5}$} & 10 & 9.1 & fghi & 87.1 & bc & 2.2 & abcde & 4.1 & $\mathrm{a}$ & 2.13 & $\mathrm{a}$ \\
\hline & 25 & 9.2 & hij & 87.2 & bc & 2.6 & bcdef & 4.2 & $\mathrm{a}$ & 3.27 & $a b c$ \\
\hline & 50 & 9.4 & $\mathrm{ij}$ & 87.2 & $\mathrm{bc}$ & 3.8 & $\mathrm{~g}$ & 11.5 & bcd & 3.53 & $a b c$ \\
\hline & 100 & 9.5 & $\mathrm{j}$ & 84.1 & $a b$ & 6.3 & $\mathrm{~h}$ & 24.6 & $\mathrm{f}$ & 8. 38 & de \\
\hline \multicolumn{2}{|c|}{$\begin{array}{l}\text { Non-amended soil } \\
\text { (Untreated control) }\end{array}$} & 8.8 & bcde & 92.5 & ef & 1.5 & $\mathrm{a}$ & 5.1 & $\mathrm{a}$ & 2.54 & $a b$ \\
\hline
\end{tabular}

ANOVA F values
Compost

Rate

Compost $x$ rate

$\begin{array}{lll}* * & * * & * \\ * * & * * & * * \\ * * & * * & * *\end{array}$

${ }^{(1)}$ Each value is an average of five replicates

${ }^{(2)}$ Data followed by the same letters on the same column are not significantly different according to Least Significant Difference's Test $(\mathrm{P} \leq 0.05)$

${ }^{(3)}$ Significant at $\mathrm{P} \leq 0.01(* *), \mathrm{P} \leq 0.05(*)$ or not significant (-) according to factorial analysis of variance 
Table 4. Global comparison of effects of the tested composts and amendment rates on soil chemical parameters at the end of the experiment

\begin{tabular}{cccccc}
\hline & \multicolumn{4}{c}{ Chemical parameters } \\
\cline { 2 - 5 } Factors & pH & $\begin{array}{c}\text { Dry } \\
\text { matter } \\
(\%)\end{array}$ & $\begin{array}{c}\text { Organic } \\
\text { matter } \\
(\%)\end{array}$ & $\begin{array}{c}\text { Ammoniacal } \\
\text { nitrogen } \\
\left(\mathrm{mg} \mathrm{kg}^{-1} \mathrm{soil}\right)\end{array}$ & $\begin{array}{c}\text { Total } \\
\text { nitrogen }\end{array}$ \\
$\left(\mathrm{g} \mathrm{kg}^{-1} \mathrm{soil}\right)$
\end{tabular}

\section{Comparison of composts}

$\begin{array}{lllllllllll}\mathbf{C}_{1} & 8.8 & \mathrm{ab} & 88.2 & \mathrm{ab} & 3.6 & \mathrm{~b} & 16.2 & \mathrm{bc} & 4.2 & \mathrm{a} \\ \mathbf{C}_{2} & 9.0 & \mathrm{bc} & 90.1 & \mathrm{bc} & 2.2 & \mathrm{a} & 17.2 & \mathrm{c} & 3.7 & \mathrm{a} \\ \mathbf{C}_{3} & 8.7 & \mathrm{a} & 91.1 & \mathrm{c} & 2.4 & \mathrm{a} & 17.1 & \mathrm{c} & 3.1 & \mathrm{a} \\ \mathbf{C}_{4} & 8.7 & \mathrm{a} & 91.4 & \mathrm{c} & 2.3 & \mathrm{a} & 11.6 & \mathrm{ab} & 3.6 & \mathrm{a} \\ \mathbf{C}_{5} & 9.3 & \mathrm{c} & 86.6 & \mathrm{a} & 3.7 & \mathrm{~b} & 11.2 & \mathrm{a} & 3.9 & \mathrm{a}\end{array}$

Comparison of amendment rates

$\begin{array}{ccccccccccc}\mathbf{0} & 9.1 & \mathrm{a} & 91.7 & \mathrm{a} & 1.6 & \mathrm{a} & 6.9 & \mathrm{a} & 2.4 & \mathrm{a} \\ \mathbf{1 0} & 8.9 & \mathrm{a} & 89.7 & \mathrm{a} & 2.0 & \mathrm{a} & 10.7 & \mathrm{~b} & 2.4 & \mathrm{a} \\ \mathbf{2 5} & 8.9 & \mathrm{a} & 90.4 & \mathrm{a} & 2.4 & \mathrm{ab} & 11.6 & \mathrm{~b} & 3.1 & \mathrm{ab} \\ \mathbf{5 0} & 9.0 & \mathrm{a} & 89.7 & \mathrm{a} & 2.8 & \mathrm{~b} & 14.9 & \mathrm{c} & 3.5 & \mathrm{~b} \\ \mathbf{1 0 0} & 8.9 & \mathrm{a} & 89.2 & \mathrm{a} & 4.2 & \mathrm{c} & 21.3 & \mathrm{~d} & 7.2 & \mathrm{c}\end{array}$

Data followed by the same letters on the same column, within each factor, are not significantly different according to Least Significant Difference's Test $(\mathrm{P} \leq 0.05)$
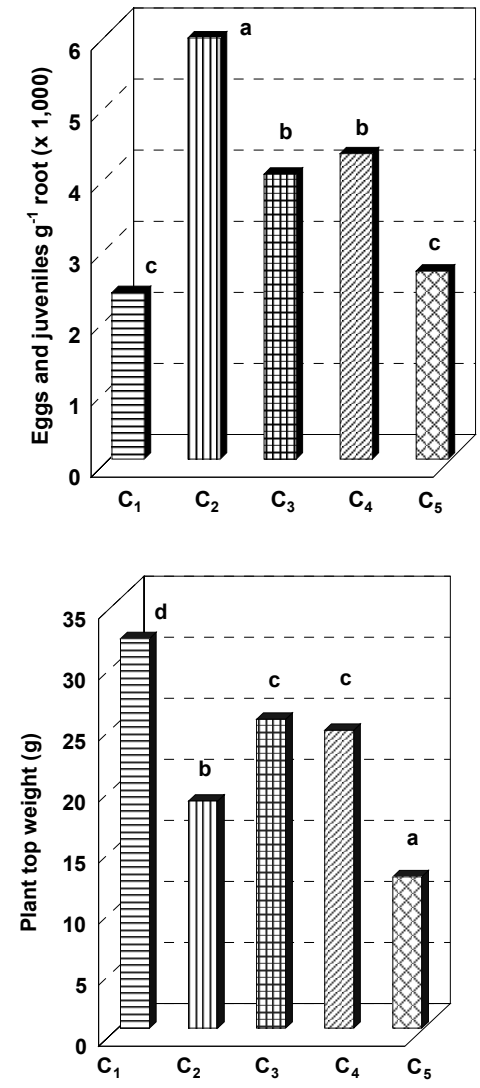

whereas intermediate values were found in $\mathrm{C}_{2}$ and $\mathrm{C}_{5}$. The highest $\mathrm{NH}_{4}{ }^{+}$content, independently from the doses, was detected in $\mathrm{C}_{2}$, followed by $\mathrm{C}_{1}$ and $\mathrm{C}_{3}$, though with significantly lower values, whereas the ammoniacal $\mathrm{N}$ fraction was almost nil in $\mathrm{C}_{4}$.

\section{Effects on soil chemical parameters}

At the end of the experiment, $\mathrm{pH}$ and $\mathrm{DM}$ content of soil amended with all composts were not significantly different from control but in the soil added with $\mathrm{C}_{5}$, presenting a significantly higher $\mathrm{pH}$ and a lower DM content in comparison to non-amended soil (Table 3). Percentage OM content was significantly increased by almost all $\mathrm{C}_{1}$ and $\mathrm{C}_{5}$ rates and only by the highest dosage of $\mathrm{C}_{2}, \mathrm{C}_{3}$ and $\mathrm{C}_{4}$. N content significantly exceeded the values of the control only at the highest rate of all composts, whereas $\mathrm{NH}_{4}{ }^{+}$was significantly increased by all rates of $\mathrm{C}_{2}$ and $\mathrm{C}_{3}$ and by the 50 and $100 \mathrm{~g} \mathrm{~kg}^{-1}$ soil rates of the other composts. Factorial analysis of variance showed that chemical parameters of the amended soil were always significantly affected by the type of compost. A statistically significant effect of amendment rate was found only on soil $\mathrm{OM}, \mathrm{N}_{\mathrm{t}}$ and $\mathrm{NH}_{4}{ }^{+}$ (Table 4).

\section{Effects on the nematode infestation}

The number of eggs and juveniles of $M$. incognita on the tomato roots was always significantly lower in all the compost-amended pots than in non-amended soil (Table 5). Among the compost treatments, the lowest nematode
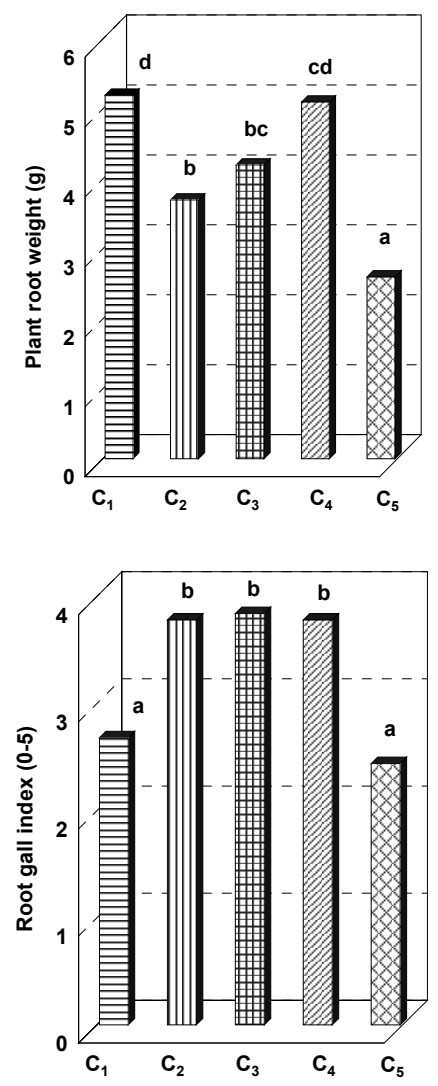

Fig. 1. Main effect of different composts on plant growth and on Meloidogyne incognita population and gall formation on tomato roots at the end of the experiment 
Table 5. Effect of the different compost treatments on the population density of $M$. incognita and on gall formation on tomato roots

\begin{tabular}{|c|c|c|c|c|c|c|}
\hline \multirow[t]{3}{*}{ Compost } & \multirow{3}{*}{$\begin{array}{c}\begin{array}{c}\text { Rate } \\
\left(\mathrm{g} \mathrm{kg}^{-1} \text { soil }\right)\end{array} \\
10\end{array}$} & \multicolumn{3}{|c|}{$\begin{array}{l}\text { M. incognita population } \\
\text { (Eggs and juveniles) }\end{array}$} & \multirow{2}{*}{\multicolumn{2}{|c|}{$\begin{array}{l}\text { Root gall index } \\
\quad(0-5)\end{array}$}} \\
\hline & & \multicolumn{2}{|c|}{ Number $\mathrm{g}^{-1}$ roots } & \multirow{2}{*}{$\begin{array}{c}\text { \% suppression } \\
76.7\end{array}$} & & \\
\hline & & $1,925^{(1)}$ & $\mathrm{g}^{(2)}$ & & 3.5 & $a b c$ \\
\hline \multirow{3}{*}{$\mathbf{C}_{1}$} & 25 & 956 & $\mathrm{i}$ & 88.4 & 2.5 & bcdef \\
\hline & 50 & 354 & $\mathrm{k}$ & 95.7 & 1.7 & def \\
\hline & 100 & 226 & $\mathrm{k}$ & 97.3 & 1.2 & $\mathrm{f}$ \\
\hline \multirow{4}{*}{$\mathrm{C}_{2}$} & 10 & 4,698 & $\mathrm{~b}$ & 43.1 & 4.0 & $a b$ \\
\hline & 25 & 4,031 & $\mathrm{c}$ & 51.1 & 3.7 & $a b c$ \\
\hline & 50 & 3,910 & $\mathrm{c}$ & 52.6 & 3.5 & $a b c$ \\
\hline & 100 & 2,802 & ef & 66.0 & 3.2 & abcd \\
\hline \multirow{4}{*}{$\mathbf{C}_{3}$} & 10 & 3,395 & d & 58.9 & 4.0 & $a b$ \\
\hline & 25 & 3,296 & d & 60.1 & 3.7 & $a b c$ \\
\hline & 50 & 3,111 & de & 62.3 & 3.5 & $a b c$ \\
\hline & 100 & 1,982 & $\mathrm{~g}$ & 76.0 & 3.5 & $a b c$ \\
\hline \multirow{4}{*}{$\mathrm{C}_{4}$} & 10 & 3,846 & $\mathrm{c}$ & 53.4 & 4.2 & $\mathrm{a}$ \\
\hline & 25 & 3,435 & d & 58.4 & 3.7 & $a b c$ \\
\hline & 50 & 3,323 & $\mathrm{~d}$ & 59.7 & 3.5 & abcd \\
\hline & 100 & 2,624 & $\mathrm{f}$ & 68.2 & 3.0 & abcde \\
\hline \multirow{4}{*}{$\mathrm{C}_{5}$} & 10 & 2,183 & g & 73,5 & 2.5 & bcdef \\
\hline & 25 & 1,347 & $\mathrm{~h}$ & 83.7 & 2.2 & cdef \\
\hline & 50 & 907 & $\mathrm{ij}$ & 89.0 & 1.5 & ef \\
\hline & 100 & 532 & $\mathrm{jk}$ & 93.6 & 1.5 & ef \\
\hline \multicolumn{2}{|c|}{$\begin{array}{l}\text { Non-amended soil } \\
\text { (Untreated control) }\end{array}$} & 8,251 & $\mathrm{a}$ & & 4.5 & $\mathrm{a}$ \\
\hline \multicolumn{7}{|c|}{ ANOVA F values } \\
\hline \multicolumn{2}{|l|}{ Compost } & 369.5 & $* *(3)$ & & 10.3 & $* *$ \\
\hline \multicolumn{2}{|l|}{ Rate } & 114.2 & $* *$ & & 4.8 & $* *$ \\
\hline \multicolumn{2}{|c|}{ Compost $x$ rate } & 3.5 & $* *$ & & 0.3 & - \\
\hline
\end{tabular}

${ }^{(1)}$ Each value is an average of five replicates

${ }^{(2)}$ Data followed by the same letters on the same column are not significantly different according to Least Significant Difference's Test (P $\left.\leq 0.05\right)$

${ }^{(3)}$ Significant at $\mathrm{P} \leq 0.01(* *), \mathrm{P} \leq 0.05(*)$ or not significant $(-)$ according to factorial analysis of variance

population densities were provided by the 50 and $100 \mathrm{~g} \cdot \mathrm{kg}^{-1}$ soil rates of $\mathrm{C}_{1}$ and by the $100 \mathrm{~g} \cdot \mathrm{kg}^{-1}$ soil rate of $\mathrm{C}_{5}$, whereas the $10-50 \mathrm{~g} \cdot \mathrm{kg}^{-1}$ soil dosages of $\mathrm{C}_{2}$ resulted in the largest number of eggs and juveniles. Soil amended with the intermediate rates of $\mathrm{C}_{2}, \mathrm{C}_{3}$ and $\mathrm{C}_{4}$ resulted in root nematode populations statistically similar among them, but significantly different from those of the extreme dosages.

Formation of galls on the roots from soil amended with all rates of $\mathrm{C}_{2}, \mathrm{C}_{3}$ and $\mathrm{C}_{4}$ did not significantly differ from the control, whereas it was statistically reduced by almost all $\mathrm{C}_{1}$ and $\mathrm{C}_{5}$ treatments without differences among the rates (Table 5).
Factorial analysis of variance evidenced a highly significant effect of both compost type and rate on the root nematode population and on the root gall formation. In particular, the number of nematodes expressed as eggs and juveniles was significantly lower on the tomato roots from soil amended with the composts $\mathrm{C}_{1}$ and $\mathrm{C}_{5}$ than with the other composts (Fig. 1). Adversely, $\mathrm{C}_{2}$ amendments resulted in a nematode density statistically higher than those provided by the other composts. The root nematode density decreased by increasing the amendment rates, though differences were statistically significant only among the extreme dosages (Fig. 2). Moreover, $\mathrm{C}_{1}$ and $\mathrm{C}_{5}$ resulted sig- 

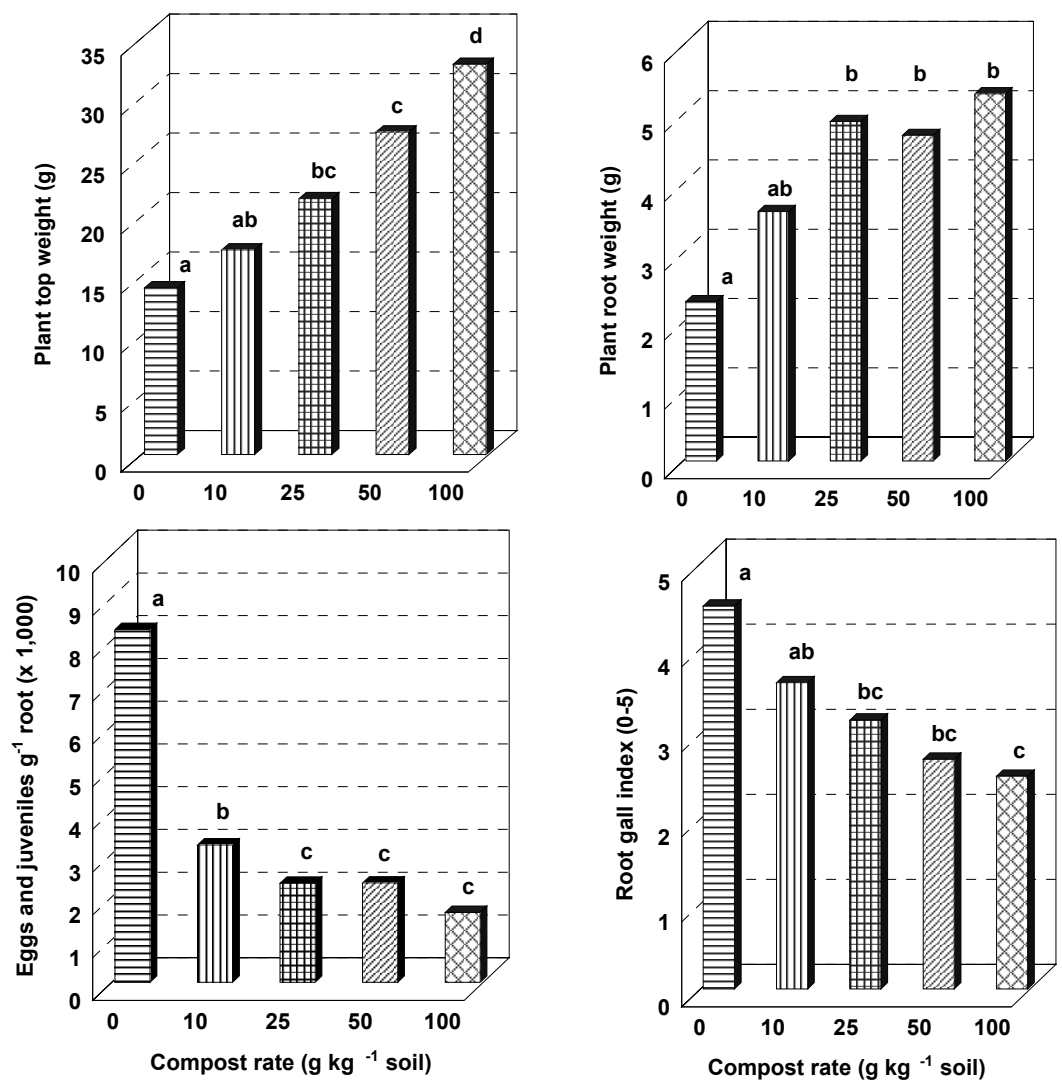

Fig. 2. Main effects of different amendment rates on plant growth and on Meloidogyne incognita population and gall formation on tomato roots at the end of the experiment

nificantly more effective than the other materials also for reducing root gall formation (Fig. 1).

An analytical relationship between amendment rate and nematode population density $\mathrm{g}^{-1}$ tomato root was also fitted to the experimental data (Fig. 3). The best fit was provided by power equation $\mathrm{y}=\mathrm{a}+\mathrm{bx}^{\mathrm{c}}$, in which: $\mathrm{y}=$ nematode population density $\mathrm{g}^{-1}$ tomato root expressed in eggs and juveniles; $\mathrm{x}=$ amendment rate; $\mathrm{a}, \mathrm{b}, \mathrm{c}=$ coefficients. The high values of the coefficients of correlation indicate that almost all the total variation in nematode population at the end of the experiment can be explained by the above relationship (Fig. 3).

\section{Effects on plant growth}

Presence of the root-knot nematode caused a strong reduction of tomato growth, as demonstrated by the largely higher plant top and root weight ( +81 and $+122 \%$, respectively) in the non-infested than in infested soil (Table 6). Soil amendments with $\mathrm{C}_{1}, \mathrm{C}_{3}$ and $\mathrm{C}_{4}$ significantly increased plant biomass in comparison to the infested control. However, the highest dosages of these composts provided a plant growth also better than the non-infested control. Adversely, growth of plants from soil amended with $\mathrm{C}_{5}$ was inconsistently or negatively affected by compost treatments, as biomass weight was not different or even significantly lower than control at all the tested rates. Treatments with $\mathrm{C}_{2}$ always resulted in a slight and not significant growth increase, but at the highest incorporation rate. A high significance of the effect of compost type was found also for the plant growth parameters, as green biomass of plants grown in soil amended with $\mathrm{C}_{1}$ was significantly heavier compared to that of other composts, whereas $\mathrm{C}_{5}$ resulted always in the lowest plant growth (Fig. 1).

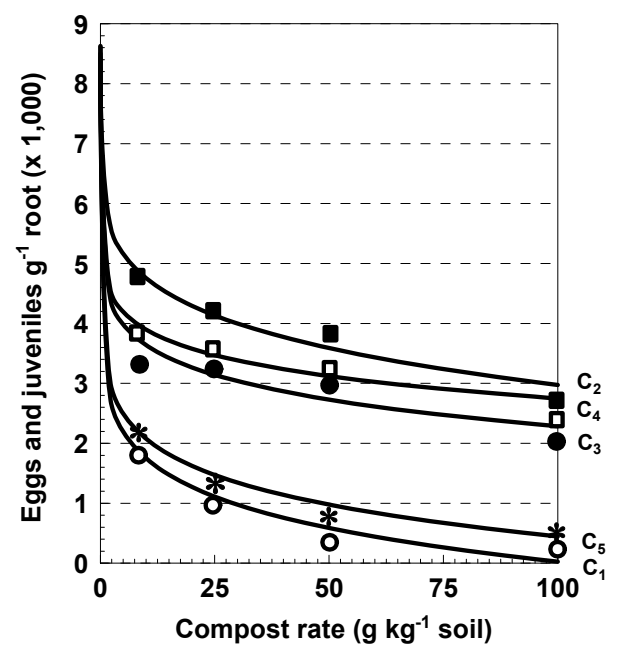

Fig. 3. Relationship between Meloidogyne incognita population density per $\mathrm{g}$ tomato root $(y)$ and incorporation rate $(x)$, according to best fitted equation $\mathrm{y}=\mathrm{a}+\mathrm{bx}{ }^{\mathrm{c}}$ and to the following equation parameters: $\mathrm{C} 1(\circ)$ : $\mathrm{a}=8,627 ; \mathrm{b}=-5,495 ; \mathrm{c}=0.0973$; $\mathrm{R}^{2}=0.996 ; \mathrm{C} 2(\mathbf{\square}): \mathrm{a}=8,263 ; \mathrm{b}=-2,323 ; \mathrm{c}=0.1787 ; \mathrm{R}^{2}=0.991 ; \mathrm{C} 3$ $(\bullet): \mathrm{a}=8,434 ; \mathrm{b}=-3,738 ; \mathrm{c}=0.1081 ; \mathrm{R}^{2}=0.986 ; \mathrm{C} 4$ ( $\left.\square\right): \mathrm{a}=8,503$; $\mathrm{b}=-3,685 ; \mathrm{c}=0.0968 ; \mathrm{R}^{2}=0.997 ; \mathrm{C} 5\left(^{*}\right): \mathrm{a}=8,613 ; \mathrm{b}=-5,231$; $\mathrm{c}=0.0967 ; \mathrm{R}^{2}=0.999$ 
Table 6. Effect of soil treatments with the different composts on tomato plant growth

\begin{tabular}{|c|c|c|c|c|c|c|c|}
\hline \multirow{3}{*}{$\begin{array}{l}\text { Treatment } \\
\text { Compost }\end{array}$} & \multirow{3}{*}{$\begin{array}{c}\begin{array}{c}\text { Rate } \\
\left(\mathrm{g} \mathrm{kg}^{-1} \text { soil }\right)\end{array} \\
10\end{array}$} & \multicolumn{6}{|c|}{ Plant weight (g) } \\
\hline & & \multicolumn{2}{|c|}{ Top } & \multirow{2}{*}{$\begin{array}{c}\text { \% increase } \\
54\end{array}$} & \multicolumn{2}{|c|}{ Root } & \multirow{2}{*}{$\begin{array}{c}\% \text { increase } \\
61\end{array}$} \\
\hline & & $21.5^{(1)}$ & $e f^{(2)}$ & & 3.7 & bcd & \\
\hline \multirow{3}{*}{$\mathrm{C}_{1}$} & 25 & 33.5 & $\mathrm{ij}$ & 139 & 6.4 & efg & 178 \\
\hline & 50 & 44.0 & $\mathrm{kl}$ & 214 & 6.5 & $\mathrm{fg}$ & 183 \\
\hline & 100 & 46.6 & 1 & 233 & 7.0 & $\mathrm{~g}$ & 204 \\
\hline \multirow{4}{*}{$\mathbf{C}_{2}$} & 10 & 17.4 & bcd & 24 & 2.9 & $a b c$ & 26 \\
\hline & 25 & 16.8 & bcd & 20 & 4.6 & $\mathrm{~d}$ & 100 \\
\hline & 50 & 17.8 & bcde & 27 & 4.0 & bcd & 74 \\
\hline & 100 & 26.8 & gh & 91 & 4.8 & de & 109 \\
\hline \multirow{4}{*}{$\mathbf{C}_{3}$} & 10 & 20.6 & de & 47 & 4.0 & bcd & 74 \\
\hline & 25 & 27.4 & gh & 96 & 5.0 & def & 117 \\
\hline & 50 & 30.2 & hi & 116 & 4.7 & de & 104 \\
\hline & 100 & 34.4 & $\mathrm{j}$ & 146 & 4.9 & def & 113 \\
\hline \multirow{4}{*}{$\mathrm{C}_{4}$} & 10 & 18.6 & cde & 33 & 3.9 & bcd & 70 \\
\hline & 25 & 20.5 & de & 46 & 4.5 & $\mathrm{~cd}$ & 96 \\
\hline & 50 & 28.6 & gh & 104 & 6.8 & g & 196 \\
\hline & 100 & 40.4 & $\mathrm{k}$ & 189 & 7.9 & g & 243 \\
\hline \multirow{4}{*}{$\mathbf{C}_{5}$} & 10 & 7.7 & $\mathrm{a}$ & -45 & 3.7 & bcd & 61 \\
\hline & 25 & 9.5 & $\mathrm{a}$ & -32 & 4.0 & $\mathrm{~cd}$ & 74 \\
\hline & 50 & 15.0 & $\mathrm{bc}$ & 7 & 1.3 & a & -43 \\
\hline & 100 & 15.9 & $\mathrm{bc}$ & 14 & 1.8 & a & -22 \\
\hline Non-amended soil & & 14.0 & $\mathrm{~b}$ & - & 2.3 & $\mathrm{ab}$ & - \\
\hline Non-infested soil & & 25.4 & $\mathrm{fg}$ & 81 & 5.1 & def & 122 \\
\hline \multicolumn{8}{|l|}{ ANOVA F values } \\
\hline Compost & & 193.3 & $* *(3)$ & & 17.6 & $* *$ & \\
\hline Rate & & 128.1 & $* *$ & & 5.8 & $* *$ & \\
\hline Compost $x$ rate & & 9.8 & $* *$ & & 3.8 & $* *$ & \\
\hline
\end{tabular}

\footnotetext{
${ }^{(1)}$ Each value is an average of five replicates

${ }^{(2)}$ Data followed by the same letters on the same column are not significantly different according to Least Significant Difference's Test $(\mathrm{P} \leq$ $0.05)$

${ }^{(3)}$ Significant at $\mathrm{P} \leq 0.01(* *), \mathrm{P} \leq 0.05(*)$ or not significant $(-)$ according to factorial analysis of variance
}

\section{Conclusions and discussion}

All compost treatments demonstrated to be suppressive on M. incognita, though at different extent and more weakly on root gall formation than on nematode population. Moreover, most composts tested in this experiment were recently found also suppressive on the cyst nematode Globodera rostochiensis Woll. on potato and on seven different plant-parasitic nematode genera in natural grassland soil (Renčo et al., 2007, 2009). Previous findings on RKN suppression by compost amendments were quite contrasting, as several authors documented a satisfactory nematode control but inconsistent results were also reported (Akhtar \& Malik, 2000).

The suppressiveness of composted organic matrices on phytoparasitic nematodes is generally considered as the resultant of different contributory mechanisms (Stirling, 1991). The release of nematotoxic nitrogenous compounds or high-molecular-weight substances, such as tannins or phenols, during the OM decomposition, can be hy- 
pothesized as primarily involved in nematode suppression in amended or treated soil (Mian \& Rodríguez-Kábana, 1982; Rodríguez-Kábana, 1986; Maistrello et al., 2010), mainly in the presence of a strictly dose-dependent suppressive effect of a compost. In our experiment, nematode suppression resulted more strictly related to compost $\mathrm{pH}$ and DM, whereas no correlation was found with $\mathrm{N}_{t}$ or $\mathrm{NH}_{4}{ }^{+}$. Moreover, an enhanced development of nematode competitors, antagonists and parasites on the feeding substrate provided by the compost was also suggested as a further mechanism of the RKN population decrease (Rodríguez-Kábana \& Morgan-Jones, 1987).

The FOP-based composts $\mathrm{C}_{1}$ and $\mathrm{C}_{5}$ resulted to be the most suppressive materials, as reducing nematode eggs and juveniles by $77-97$ and $73-94 \%$, as confirming the high root-nematode suppressiveness previously documented for raw and composted FOP (D'Addabbo \& Sasanelli, 1997; Marull et al., 1997; D'Addabbo et al., 2003). The phytotoxicity of the highest rates of $\mathrm{C}_{5}$ may be probably related to the high $\mathrm{pH}$ of this material (Arvanitoyannis \& Kassaveti, 2007).

In both $\mathrm{C}_{1}$ and $\mathrm{C}_{5}$, FOP was combined with a nitrogenous waste material as sheep wool wastes and chicken manure, respectively. Nitrogen content of the waste materials added to FOP in composting mixture can consistently affect the nematode suppressiveness of compost, as improved or limited by the combination with high or low-nitrogen wastes, respectively (Oka \& Yermiyahu, 2002; Nico et al., 2004). This synergism of nitrogenous materials with FOP wastes could be attributed to the enhancement of both nematicidal mechanisms above described for compost soil amendments (Raviv et al., 2005).

Our experiment is the first report of the suppressive activity of a mushroom substrate-based compost, as $\mathrm{C}_{3}$, on RKN, as it was previously stated against Pratylenchus penetrans on potato and various trichodorid nematode species on ornamental bulb crops (LaMondia et al., 1999; Zoon et al., 2002).

The lowest suppressive effect on the population of $M$. incognita was exhibited by the composts derived from municipal green wastes, $\mathrm{C}_{4}$ and $\mathrm{C}_{2}$, as confirming the poor effect of composted yard-wastes (leaves, branches, grass clippings) on root-knot nematodes stated also by other authors (McSorley \& Gallaher, 1995; Kimpinski et al., 2003). Also the combination of green wastes with sewage sludge, as provided by $\mathrm{C}_{4}$, was always found to result in inconsistent or even negative effects on the nematode activity of the derived compost (Mannion et al., 1994; McSorley et al., 1997).

Tomato plant growth was positively affected by all treatments with $\mathrm{C}_{1}, \mathrm{C}_{3}$ and $\mathrm{C}_{4}$ and only by the highest rates of $\mathrm{C}_{2}$, whereas $\mathrm{C}_{5}$ was not plant beneficial or even phytotoxic. Beneficial plant growth effects of compost amendments are mainly related to the release of nutrients as well as to an improved drainage and water retention in the amended soils, though stimulation of growth-promoting microorganisms and biocontrol agents in the plant rhizosphere may also be a contributory mechanism (Chen \& Inbar, 1993;
Alvarez et al., 1995;). However, the comparison among data from compost treatments and those of the infested and noninfested controls may suggest that the growth effect of the tested materials may be concurrently due to an increased plant nutrition, as exerted mainly by $\mathrm{C}_{1}$ and $\mathrm{C}_{3}$, as well as to the nematode suppression, prevailing in the soil amended with $\mathrm{C}_{4}$. Composts from many raw materials, among which manures and FOP, were reported for a general improvement of physical soil properties and availability of nutrients (Sasanelli et al., 2002; Al-Widyan et al., 2005 ), though in our experiment $\mathrm{N}_{t}$ content was consistently enriched only at the highest rates of the five materials and OM content was improved mainly by FOP composts. Finally, the soil $\mathrm{pH}$ was not affected by compost amendments and, therefore, could not be related to their nematicidal effect. Adversely, a significant correlation between soil $\mathrm{pH}$ increase and disease suppressiveness of composts was previously documented (Termorshuizen et al., 2005).

All the tested compost could play a relevant role for a sustainable management of RKN, though the highest applicative potential was surely shown by $\mathrm{C}_{1}$, as joining a high nematode suppressiveness to a remarkable plant growth effect. In addition, the local availability of the raw components of this compost, i.e. FOP, sheep wool wastes and wheat straw, allows to reduce the costs of the composting process and offers, at the same time, a safe alternative for the disposal of large amounts of these biowastes. The other composts, though possessing a suppressive potential, still need a standardization of the source raw materials and of the composting process, as to ensure constant and predictable effects on nematode and crop and to avoid phytotoxicity phenomena.

\section{Acknowledgements}

The research was undertaken within the framework of a bilateral project between the Italian National Council of Research and the Slovak Academy of Sciences (20102012). The authors acknowledge the support of the scientific grant agency VEGA (Grant $\mathrm{N}^{\circ} 2 / 0136 / 10$ and Grant $\left.\mathrm{N}^{\circ} 2 / 0147 / 10\right)$ and Mr. Fabio Catalano for technical assistance.

\section{References}

AKHTAR, M., MALIK, A. (2000): Roles of organic soil amendments and soil organisms in the biological control of plant-parasitic nematodes: a review. Bioresource Technol., 74: 35 - 47. DOI: 10.1016/S0960-8524(99)00154-6

Alvarez, M. A., Gagné, S., Antoun, H. (1995): Effect of compost on rhizosphere microflora of the tomato and on the incidence of plant growth-promoting rhizobacteria. Appl. Environ. Microbiol. 61: $194-199$

Al-Widyan, M. I., Al-ABed, N., Al-Jalil, H. (2005): Effect of composted olive cake in soil physical properties. Comm. Soil. Sci. Plant Anal. 36: 1199 - 1212. DOI: 10.1081/CSS-200056896 
Arvanitoyannis, I. S., Kassaveti, A. (2007): Current and potential uses of composted olive oil waste. Int. J. Food Sci. Tech., 42: 281 - 295. DOI:10.1111/j.13652621.2006.01211.x

BAILEY, K. L., LAZAROVITS, G. (2003): Suppressing soilborne diseases with residue management and organic amendments. Soil Till. Res., 72: 169 - 180. DOI: 10.1016/ S0167-1987(03)00086-2

BREMNER, J. M. (1996): Nitrogen - total. In: SPARKS, D. L. (Ed) Methods of soil analysis. Part 3 - chemical methods. Madison, WI, USA: Soil Science Society of America, Book Series 5, pp. $1085-1121$

CHEN, Y., InBAR, Y. (1993): Chemical and spectroscopical analyses of organic matter transformations during composting in relation to compost maturity. In: HoITINK H. A. J., KEENER H. M. (Eds) Science and Engineering of Composting: Design, Environmental, Microbiological, and Utilization Aspects. Renaissance Publications, Worthington, $\mathrm{OH}$

D’Adddabbo, T., Sasanelli, N. (1997): Suppression of Meloidogyne incognita by combination of olive pomace or wheat straw with urea. Nematol. Mediterr., 25: 159 - 164 D’Addabbo, T., Sasanelli, N., Lamberti, F., Greco, P., CARella, A. (2003): Olive pomace and chicken manure amendments for control of Meloidogyne incognita over two crop cycles. Nematropica 33: $1-7$

DE BERTOLDI, M. (2008): Production and utilization of suppressive composts: environmental, food and health benefits. In: Insam, H., Franke-Whittle, I., Goberna, M. (Eds) Microbes at work: from wastes to resources. Berlin, Heidelberg, Germany: Springer-Verlag, pp. 153 - 170 Greco, N., Esmenjaud, D. (2004): Management strategies for nematode control in Europe. In: COOK, R., HuNT, D. J. (Eds) Nematology monographs and perspectives. Leiden, The Netherlands: Brill Press, pp. $33-43$

HU, C., QI, Y.C. (2010): Abundance and diversity of soil nematodes as influenced by different types of organic manure. Helminthologia, 47: 58 - 66, DOI: 10.2478/ s11687-010-0009-8

Hussey, R. S., BARKER, K. R. (1973): A comparison of methods of collecting inocula of Meloidogyne spp. including a new technique. Plant Dis. Reptr., 57: 1025 - 1028 Kimpinski, J., Gallant, C. E., Henry, R., Macleod, J. A., Sanderson, J. B., Sturz, A. V. (2003): Effect of compost and manure soil amendments on nematodes and on yields of potato and barley: A 7-year study. J. Nematol., 35: $289-293$

LaMondia, J. A., Gent, M. P. N., Ferrandino, F. J., Elmer, W. H., Stoner, K. A. (1999): Effect of compost amendment or straw mulch on potato early dying disease. Plant Dis. 83: 361 - 366. DOI: 10.1094/PDIS.1999.83.4.361 Maistrello, L., VacCari, G., SASAnelli, N. (2010): Effect of chestnut tannins on the root-knot nematode $\mathrm{Mel}$ oidogyne javanica. Helminthologia, 47: 48 - 57. DOI: 10.2478/s11687-010-0008-9

Mannion, C. M., Schaffer, B., Ozores-Hampton, M., BRYAN, H. H., MCSORLEY, R. (1994): Nematode population dynamics in municipal solid waste-amended soil during tomato and squash cultivation. Nematropica, 24: $17-24$ Marull, J., Pinochet, J., Rodriguez-KabanA, R. (1997): Agricultural and municipal compost residues for control of root-knot nematodes in tomato and pepper. Compost Sci. Util., 5: $6-15$

MCSORley, R., GALlaher, R. N. (1995): Effect of yard waste compost on plant-parasitic nematode densities in vegetable crops. J. Nematol., 27: 545-549

McSorley, R., Stansly, P. A., Noling, J. W., Obreza, T. A., CONNER, J. M. (1997): Impact of organic soil amendments and fumigation on plant-parasitic nematodes a southwest Florida vegetable field. Nematropica 27: 181 - 189

Mian, I. H., RodRiguEZ-KÁBAnA, R. (1982): Survey of the nematicidal properties of some organic materials available in Alabama as amendments to soil for control of Meloidogyne arenaria. Nematropica, 12: 235 - 246

Mulvaney, R. L. (1996). Nitrogen-inorganic forms. In: SPARKS, D. L. (Ed) Methods of soil analysis. Part 3 Chemical methods. Madison, WI, USA, Soil Science Society of America, Book series 5, pp. 1123 - 1184

Nico, A. I., Jimenez-Diaz, R. M., CAstillo, P. (2004): Control of root-knot nematodes by composted agro-industrial wastes in potting mixtures, Crop Prot., 23: 581 587. DOI: 10.1016/j.cropro.2003.11.005

OKA, Y., YERMIYAHU, U. (2002): Suppressive effects of composts against the root-knot nematode Meloidogyne javanica on tomato. Nematology, 4: $891-898$

Raviv, M., OKa, Y., Katan, J., Hadar, Y., Yogev, A., Medina, S., Krasnovsky, A., Ziadna, H. (2005): Highnitrogen compost as a medium for organic container-grown crops. Bioresource Technol., 96: 419 - 427. DOI: 10.1016/j.biortech.2004.06.001

Renčo, M., D'AdDabbo, T., Sasanelli, N., Papajová, I. (2007): The effect of five composts of different origin on the survival and reproduction of Globodera rostochiensis. Nematology 9: 537 - 543. DOI: 10.1163/15685410778 1487260

RenČO, M., SASANelli, N., ŠAlamún, P. (2009): The effect of two compost soil amendments, based on municipal green and penicillin production wastes, on plant parasitic nematodes. Helminthologia, 46: 190 - 197. DOI: 10.2478/s11687-009-0035-6

RenČO, M., SASAnelli, N., KovÁČIK, P. (2011): The effect of soil compost treatments on potato cyst nematodes Globodera rostochiensis and Globodera pallida. Helminthologia, 48: 184 - 194. DOI: 10.2478/s11687-011-0027-1 RODRÍGUEZ-KÁBANA, R. (1986): Organic and inorganic amendments to soil as nematode suppressants. J. Nematol., 18: $129-135$

Rodríguez-KÁBAnA, R., MORGAn-Jones, G. (1987): Biological control of nematodes: soil amendments and microbial antagonists. Plant and Soil 100: 237-247

Sasanelli, N., D’Addabbo, T., Convertini, G., Ferri, D. (2002): Soil Phytoparasitic Nematodes Suppression and Changes of Chemical Properties Determined by Waste Residues from Olive Oil Extraction. In Proceedings of $12^{\text {th }}$ ISCO Conference, May 26-31, 2002 Beijing China. Vol. III: $588-592$ 
STIRLING, G. R., 1991. Biological control of plant parasitic nematodes. CAB International: Wallingford, U.K.

TAYLOR, A. L., SASSER, J. N. (1978): Biology, Identification and Control of Root-Knot Nematodes (Meloidogyne spp.). Raleigh (NC): North Carolina State University Graphics. pp. 111

TERMORSHUIZEN, A. J., VAN RIJN, E., VAN DER GAAG, D. J., Alabouvette, C., Chen, Y., LagerlöF, J., MalandraKis, A. A., Paplomatas, E. J., RÄMert, B., RYckebOer, J., SteinBerG, C., ZMORA-NAHUM, S. (2006): Suppressiveness of 18 composts against 7 pathosystems: variability in

RECEIVED NOVEMBER 9, 2010 pathogen response. Soil Biol. Biochem., 38: 2461 - 2477. DOI: 10.1016/j.soilbio.2006.03.002

Williams P. T. (2005): Waste treatment and disposal. John Wiley \& Sons, Chichester, UK.

Zhang, W., Hoitink, H. A. J., Dick, W. A. (1996): Compost-induced systemic acquired resistance in cucumber to Pythium root rot and anthracnose. Phytopathol., 86: $1066-$ 1070

Zoon, F. C., van Bruggen, A. S., De Heij, A., Asjes, C.J., VAN DEN ENDE, J. E. (2002): Effect of green manure crops and organic amendments on incidence of nematode-borne tobacco rattle virus. Acta Hortic., 570: 287 - 292

ACCEPTED JUNE 29, 2011 